\title{
Study and comparative approach to materials used in ancient Egypt and the modern era
}

\author{
Lynda Amel Chaabane ${ }^{1} \cdot$ Hamza Soualhi $^{2}$ (i) $\cdot$ Nabil Matari $^{1} \cdot$ Nelia Benmokhtar $^{1} \cdot$ Nadia Sirine Bouayed $^{1,3}$. \\ Tedjeddine Bendisari ${ }^{1}$
}

Received: 15 November 2021 / Accepted: 7 February 2022 / Published online: 18 February 2022

(c) Saudi Society for Geosciences 2022

\begin{abstract}
It is widely recognized that today people around the world still admire the Egyptian civilization and wonder how Egyptians came to manufacture mortar. The present work aims to study the construction materials that were used in ancient Egypt and their development over time. To do this, it was decided to first evaluate the physical and mechanical performances of the building materials used at that time and then try to investigate and understand the handling process as well as the construction methods adopted currently. For this, cement (NA442 CEM II/B-L $42.5 \mathrm{~N}$ ) and local sand were replaced at different proportions with lime in the formulation of mortar, the sand used whose mixture was relative to that of the sand (0/4) and (0/1) values of $65 \%$ and $35 \%$, respectively. A number of tests were carried out on two types of mortar prepared with two different formulations. The first formulation, which included quicklime, was subjected to a simple treatment in order to obtain aerial lime and to understand the different formulation stages that were followed in the Ancient Egyptian times. Knowing that the objective was to revive the method of manufacturing works from the ancient era, thus using a variable rate of substitution $(0 \%$, $50 \%$ to $70 \%$ ) of lime, limestone and gypsum to obtain the binder by also studying the stakes of this variation on the reduction of the quantity of cement in the mortar which consisted in the preparation of fourteen test series in order to converge on the impact of the experiments sought. The second one consisted, at a later time, in preparing some series of mortar incorporating aerial lime brought from the manufacturing plant. After analyzing the prepared material, it was deemed interesting to attempt to quantitatively reconstruct the composition of the material using the Vicat test for the purpose of assessing the cement slurry setting process for stylolithic joints which, to the best of our knowledge, are very well developed only in limestones. Also noting that, the composition of the mortar and the rate of substitution evolved according to the results obtained upstream while keeping the objective of this research which was to reproduce a composition compatible with the old days.
\end{abstract}

Keywords Pyramids $\cdot$ Local materials $\cdot$ Mortars $\cdot$ Physical tests $\cdot$ Mechanical tests $\cdot$ Grout

\section{Introduction}

All building remains, such as the Vault of the Pantheon in Rome, the paintings of the Villa of the Mysteries in Pompeii, the Zeugma Mosaic Museum in Turkey, and many others, are

Responsible Editor: Zeynal Abiddin Erguler

Hamza Soualhi

hamza_s26@yahoo.fr

1 Civil Engineering Department, University of Djillali Liabes, 22000 Sidi Bel Abbes, Algeria

2 Civil Engineering Research Laboratory (LRGC), University of Amar Telidji, P.O. Box 37G, 03000 Laghouat, Algeria

3 University of La Havre, Le Havre 76600, France well known and famous for the quality of their style and workmanship. The decorations and architecture of the buildings allow those who know how to appreciate them to reveal all the decorative and architectural science of the Romans; they can also help us to identify the ideology behind these remains and to understand the reasons for their creation and the concerns about their realization. In short, these decorations and architecture tell us a lot about the Roman society (Arnaud Coutelas 2009).

A few analyses reported by researchers on the use of clays and clay-based natural minerals are important and versatile raw materials for a wide range of applications going from traditional industry like pottery to agriculture and construction. Industrial processes usually take benefits of the plasticity of clay pastes which facilitates their shaping into green bodies, the latter can be converted into ceramic pieces by 
convenient thermal treatment. Beside the intrinsic properties of clay-based products after firing, both low-cost and local accessibility are the most important factors of choice that motivate the common use of these natural materials worldwide (El Korhani et al. 2019).

According to Muzahim Al-Mukhtar (2005) and PachecoTorgal et al. (2012), the presence of lime is the main reason for the durability of stone constructions. It should be noted that mortars incorporating lime, which is obtained from calcined limestone, gypsum, and sand, as well as shells, were encountered on luxurious structures such as the temples and palaces of Pergamon, an ancient Greek city. In Egypt, the great pyramids were covered with a protective smooth layer which, after analysis and thorough examination, revealed the presence of clay, aerial lime, and quartz sand (Weber \& Broutin 2007).

Some researchers have evoked that the (Muzahim AlMukhtar 2005; Beck et al. 2007) calcite is found as a minor constituent in aerial lime, while it is a major constituent in hydraulic lime. In this context, Beck et al. found out that quartz $\left(\mathrm{SiO}_{2}\right)$ and belite $\left(\mathrm{Ca}_{2} \mathrm{SiO}_{4}\right)$ together constitute about $30 \%$ of hydraulic lime (Beck et al. 2007). This type of lime is quite dense due to the presence of calcite and belite. However, according to Beck et al. (2007), aerial lime appears finer than hydraulic lime because the largest grains of aerial lime do not exceed $50 \mu \mathrm{m}$ in diameter, while the size of grains constituting hydraulic lime can be as large as $150 \mu \mathrm{m}$. It is worth recalling that calcite is generally present as a minor constituent in aerial lime, while it is predominant in hydraulic lime.

Many researchers reported the absence of lime in mortars (Michel Frizot 1975; Sumera and Veyrat, 1997; Bénédicte Palazzo-Bertholon 1999; Vaschalde et al. 2016). Other works confirmed succeeded in identifying weakly hydraulic lime or magnesian lime in constructions of ancient and medieval times (Martinet and Quenee; Charola et al. 1984; Bénédicte Palazzo-Bertholon 1999; Arnaud Coutelas 2003, 2009; Mannoni et al. 2006; Mertens et al. 2006). Therefore, the idea of exclusively using aerial lime or fat lime prior to the industrial revolution was widely spread in the archeological literature (Arnaud Coutelas 2009). Research on the lime manufacturing industry of the Midi (Vaschalde et al. 2010) made it possible to change the direction of research by attempting to study lime not of mortars but rather of kilns. Consequently, it has been was deemed interesting to concentrate on an unprocessed material, which allowed overcoming the different problems related to the chemical interactions that are usually observed in mortars, between lime and additives such as sand, broken tile, and pozzolan (Vaschalde et al. 2016).

Furthermore, investigators carried out ethnoarchaeological surveys in the Maghreb for the purpose of determining the quantity of materials that can be loaded and stirred in the ovens or even of adding others (Vaschalde et al. 2016). The question of representativeness of each one of the samples taken in relation to the original lime layer quickly arose, particularly when atypical mineralogical phases appeared (Vaschalde et al. 2016).

On the other hand, because the compatibility between the new repair mortar and conventional masonry components is essential for the structure (Peter 2001), there has subsequently been increasing interest in the use of lime-based mortars in the restoration of historical monuments (Maamar 2009). According to Bouanane Khentouche (2008), this compatibility can be considered under several aspects: the chemical compatibility between the applied mortar and ancient stones, bricks, and mortars (STAP du Calvados 2013); the physical compatibility that was particularly linked to solubility and water transport (Kribeche J 2012), and the structural and mechanical compatibility which is represented by similar mechanical forces.

It is worth specifying that Vaschalde et al. (2016) observed and reported a granular disintegration or arenization in the old soil and especially under cement patches, due to the crystallization of salts in the interface between stone and cement (Vaschalde et al. 2016). After the removal of the brick and cement mortar fillings, the alteration of the sandstone under the waterproof and rigid adhesives was clearly noticed, and these adhesives form a cover that prevents the circulation of water and the escape of salts. When the joints are injected with pure cement milk, the disintegration can reach 10 to $15 \mathrm{~cm}$ in depth. It is also that, even nowadays, the mortars used on construction sites in Kanak contain in their formulation a significant proportion of white cement associated with local lime; moreover, based on the literature review, researchers did not choose arbitrary materials; they only selected those including the white cement used by the Egyptians of our time. This white cement has the same characteristics as ours according to the research results reported by Pieri (2019).

Furthermore, several researchers, such as Anas and Chaabane (2019), found out that the sand used in this article is of particular interest because, according to the literature, this North African sand is quartzite in nature (Weber et Broutin 2007) as it contains silica that is widely used in local materials. We notice that the Egyptians being in lack of technical and material means knew how to innovate and develop materials including lime which is ideal for renovating the structures, vestiges in order to preserve their splendor and their historical and cultural significance. On the other hand, the binder which is cement, a modern material, which cannot be used for such works due to its inadequate properties for the renovation and rehabilitation of old constructions, the latter being is the centerpiece to assemble the stones associated also to temperature rise in the desert, the taking of which must have been rapid in the ancient era, the research of ancient civilizations in the elaboration of monuments 
considered as fantastic, by comparing with the modern era where the control of the components of the current binder is more identified as well as the additive which allows on the site to put gauges in the installation of the material and its objectives.

\section{Materials and methods}

In order to carry out the tests, it was deemed important to study, in the first section, the characteristics of the different materials used in the composition of lime-based mortar. These characteristics are the density, granulometry, cleanliness, chemical and mineralogical composition, as well as other physical properties, in order to achieve a good interpretation of the various experimental results.

\section{Cement}

The cement used is Portland limestone cement NA442-CEM II/B-L 42.5 N ES, coming from LAFARGE Cement Plant, and in conforms to Algerian (NA442-2013) and European (EN 197-1) Standards. This choice was established on the basis of some research results previously reported by several authors who indicated that the selected cement is Egyptian white cement with a stress of about $50 \mathrm{MPa}$ which is twice as high as that of sandstone (Martinet 1992; Pieri 2019). The chemical and mineralogical characteristics of cement are presented in Table 1 .

\section{Sand}

\section{Physical characteristics}

In this study, the test conducted in this section aimed to determine the particle size distribution of the granular materials used. In order to exploit local materials and allow their recycling, it was decided to use a mixture of two types of sands of fractions (0/3) and (0/1), as shown in Table 1. The physical identification of the two types of sand made it possible to determine the appropriate proportions of a new mixture. The properties of materials depend on the size of the particles that compose them. It should be noted that the granular spindle obtained after mixing the two types of sand must meet the requirements of the NF EN 933-1 Standard actually in force.

The results obtained and analyzed in the laboratory for the cumulative undersize of the two sands are clearly presented in Fig. 1 (Table 2).

\section{Particle size analysis}

The particle size analysis, carried out according to Standard NF P 18-560, allows using different sieve sizes in order to accurately determine the composition of the material under study and then to deduce its physical characteristics. The test in question consisted of splitting the material, by means of a series of sieves, into several granular classes of decreasing sizes. The different oversize and undersize masses are related to the initial mass of the material. The percentages thus obtained are used in a graphical form, as illustrated in Fig. 2. It is worth indicating that sand is an important element in the formulation of the coating; it gives that coating sufficient porosity to guarantee the necessary air supply for

Table 2 Main physical characteristics of sands

\begin{tabular}{lll}
\hline Physical characteristics & Sand $(0 / 3)$ & Sand $(0 / 1)$ \\
\hline Sand equivalent $(\%)$ & 33.7 & $/$ \\
Absolute density $\left(\mathrm{kg} / \mathrm{m}^{3}\right)$ & 2645 & 2659 \\
Apparent volumetric mass $\left(\mathrm{kg} / \mathrm{m}^{3}\right)$ & 1480 & 1327 \\
\hline
\end{tabular}

Table 1 Chemical, mineralogical, and physical characteristics of cement

\begin{tabular}{llc}
\hline Chemical properties & Loss on ignition (\%) (NA 5042) & $10.0 \pm 2$ \\
& Sulfate content (\%) & $2.5 \pm 0.5$ \\
& Magnesium oxide content (\%) & $1.7 \pm 0.5$ \\
& Chloride content (\%) (NA 5042) & $002-0.05$ \\
Mineralogical composition of clinker (bogue) & C3S (\%) & $60 \pm 3$ \\
& C3A (\%) & $7.5 \pm 1$ \\
Physical properties & Normal consistence (\%) & $26.5 \pm 2$ \\
& Finesse (cm ${ }^{2} /$ g) (NA231) & $3700-5200$ \\
& Shrinkage at 28 days ( $\mu \mathrm{m} / \mathrm{m})$ & $<1000$ \\
Setting time at $20^{\circ} \mathrm{C}(\mathrm{NA} 230)$ & Expansion (mm) & $\leq 3.0$ \\
& Start of setting (hour) & $2 \mathrm{~h} 30$ \\
Compressive strength & End of setting (hour) & $4 \mathrm{~h}$ \\
& 2 days (MPa) & $\geq 10.0$ \\
& 28 days (MPa) & $\geq 42.5$ \\
\hline
\end{tabular}




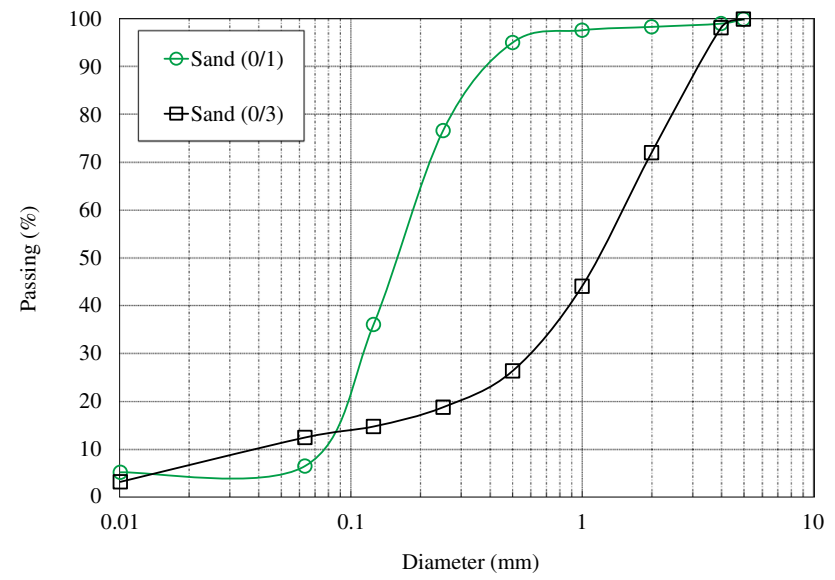

Fig. 1 Particle size analysis of the two sands

its setting and provides it with adequate permeability thereafter (Pieri 2019).

On the other hand, according to the results obtained from the two granulometric analysis curves presented in Fig. 2, the fineness modulus may be used to assess the granularity. The fineness moduli obtained are equal to 3.74 and 1.09 for the fractions (0/3) and (0/1), respectively. Note that sand $\mathrm{SN}$, obtained after mixing, is characterized by a fineness modulus equal to 2.5 .

Besides, the granularity of sand meets the conditions required for the jointing used on sidewalks when laying paving slabs of natural stone, concrete, and brick according to PTV 400 and 402 (Qualiroutes 2011).

\section{Mixing water}

The water used in the preparation of mortars meets the requirements of Standard NF P 18-303.

\section{Lime}

The lime comes from a local region of the city of Saida in Algeria produced by the company BMSD-SARL where the physical and chemical properties of lime (calcium oxide$\mathrm{CaO}$ ) used at the start of this work are summarized in Table 3.

The results obtained show that this is fat lime in powder form with size ranging from 0 to $2 \mathrm{~mm}$. It is suitable for making grouts with an apparent density equal to $0.78 \mathrm{~g} /$ $\mathrm{m}^{3}$ and an active carbonation rate greater than or equal to 90, which is sufficient for the hardening of paste knowing that the setting of lime is slow in contact with carbon dioxide of the air.

\section{Formulation of mortars}

The tests were carried out on mortars with standard compositions, and the control mortar includes cement (100\%), sand, and water; the second formulation includes lime (100\%), sand, and water. Based on the standard preparation, it was decided to develop a series of other mortars by

Table 3 Physical and chemical characteristics of lime

\begin{tabular}{ll}
$\begin{array}{l}\text { Physical properties } \\
\text { Granulometry }\end{array}$ & $\begin{array}{c}\text { A piece of lime } \\
\text { between } 8 \text { and } \\
15 \mathrm{~mm}\end{array}$ \\
& $\begin{array}{l}\text { Powder } 0-2 \mathrm{~mm} \\
\\
\end{array}$ \\
Apparent density & $0.78 \mathrm{~g} / \mathrm{cm}^{3}$ \\
Molecular weight & $56.08 \mathrm{~g} / \mathrm{mole}^{3}$ \\
Physical state & Solid \\
Chemical characteristics of lime & \\
Total CaO & $96.83 \%$ \\
Active $\mathrm{CaO}$ & $\geq 90 \%$ \\
Reactivity $\mathrm{t}_{60}$ & $<2 \mathrm{~mm}$ \\
Residual $\mathrm{CO}_{2}$ & $<2 \%$ \\
\hline
\end{tabular}

Fig. 2 Spreading of the different mortars
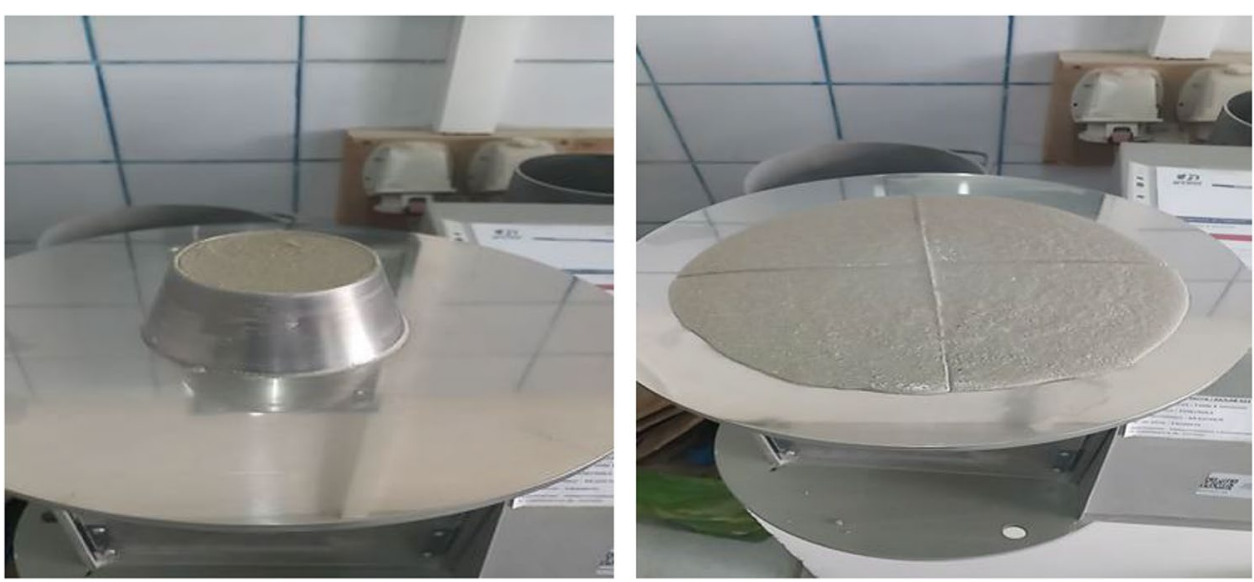
modifying the contents of cement and lime into the mixture. The cement and lime contents were respectively $50 \%$ and $50 \%$. The different samples were prepared by varying the water-to-cement (W/C) ratio which took the values 0.5 , 1.15 , and 1.4. The samples were prepared in the laboratory under the atmospheric conditions of the laboratory, at an ambient temperature of $20 \pm 2{ }^{\circ} \mathrm{C}$, according to Standard NF EN 196-1. The other series were manufactured under the same conditions by replacing different mass fractions of cement by lime, while the quantities of sand (granular skeleton) remained unchanged. Moreover, the mortar mixes were prepared following the same procedure.

In order to meet the set objectives, three series of mortars were prepared manually by varying the proportions of aerial lime and cement, as well as the water-to-cement (W/C) ratio. The compositions of the different mortars under study are summarized in Table 4.

\section{Results and discussion}

\section{Tests on fresh mortar}

\section{Influence of lime on the physical properties of fresh mortars}

Spreading tests on a shaking table From the start, the approach adopted consisted in carrying out several experiments on different materials; some physical tests and mineralogical analyses were then conducted in the laboratory. This allowed gaining more insight into the main characteristics of the materials used in the formulation of mortars that are supposed to be studied in this research work. It should be recalled that the present study aims to investigate the influence of lime, as a cement replacement, on the physicomechanical characteristics of the mortars under study, for different (W/C) ratios.

The purpose of this section is to study the impact of the different binders on the samples tested. For this, various mortar mixes were made for the purpose of evaluating their workability, in accordance with Standard EN 12-358. The mortars were named as follows:

\section{MRCH (100\% fat lime) \\ MRCmCH (50\% cement, 50\% lime) \\ MRcag (80\% limestone, 20\% gypsum) \\ MRCHc (80\% aerial lime, $20 \%$ limestone)}

Figure 2 and Fig. 3 explicitly indicate that the results of workability test of the mortars under study, using the shaking table in accordance with Standard EN 12-358, can be used to obtain the spread measurements, as is clearly illustrated on the histogram of Fig. 3. We observe that for the $\mathrm{MRCmCm}$ series, $\mathrm{MRCmCH}$ containing cement, the spread variation is around $87.64 \%$. While for the difference obtained from the MR cag and MR ccal series where the substitution of the cement was lime transformed into aerial lime and the limestone illustrates a spreading difference of $94.73 \%$, indicates that there is a consistency between the surface specific fine of these materials which apparently does not contribute to the fluidity of the mixture as well as the reduction in the diameter of the spreading linked to the plasticity

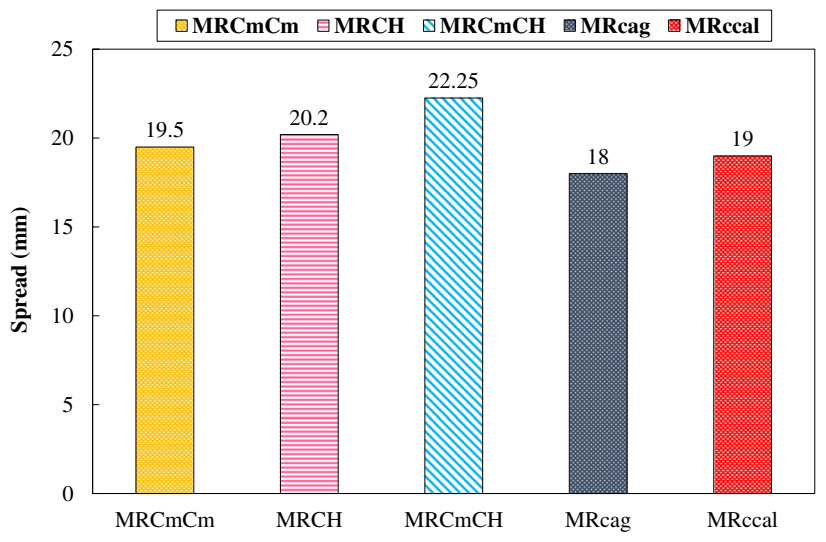

Fig. 3 Histograms of the spread of different mortar compositions

Table 4 The different compositions of the mortars under study

\begin{tabular}{llllllllll}
\hline Mix & W/C & Cement $(\mathrm{g})$ & Aerial lime $(\mathrm{g})$ & Water $(\mathrm{g})$ & Limestone $(\mathrm{g})$ & Gypsum $(\mathrm{g})$ & $\begin{array}{l}\text { Hydraulic } \\
\text { lime }(\mathrm{g})\end{array}$ & Sand 0/1 (g) & Sand 0/4 (g) \\
\hline M1 & 1.4 & - & 450 & 630 & - & - & - & 405 & 945 \\
M2 & 1.15 & 225 & 225 & 517.5 & - & - & - & - & 1350 \\
M3 & 0.5 & 450 & - & 225 & - & - & - & 405 & 945 \\
MRCH & - & - & 450 & 235 & - & - & 450 & 405 & 945 \\
MRCmCH & 0.434 & 225 & 225 & 517.5 & - & - & - & 405 & 945 \\
MRcag & - & - & - & 700 & 360 & 90 & - & 405 & 945 \\
MRCHc & 1.30 & - & - & 185 & 90 & - & 360 & 405 & 945 \\
\hline
\end{tabular}


of the material, what was also noted by Azeredo et al. 2007 . This observation is certainly due to the fact that very small amounts of uncombined silica (quartz) exist in the materials. This free alumina, which is found in the form of gibbsite, increases towards the top of the profiles. Its presence characterizes a more advanced stage in the evolution of kaolinite degradation, a stage that would not be reached in the case of soils containing sandstone materials, probably due to the fact that these soils are rich in uncombined silica. It is useful to remember that silica (quartz) can be effective solely when it is released in sufficient quantity in the solution, allowing the alumina to recombine to form again kaolinite. In this context, Fauck (1973) explicitly indicated that when the quartz contents are insufficient, this recombination would not occur.

On the other hand, R. Fauck (1973) indicated that the morphological convergence of red ferrallitic soils on sandstone and basalt depends on common characters, in particular on reddening and the creation of pseudo-particles. However, lime presents several important differences such as the presence of free alumina.

On the other hand, Fig. 2 and Fig. 3 clearly show that the workability tests of the various mortar mixes under study were carried out in accordance with standard EN 12-358. In addition, regarding the measurement of the spreading, as represented on the histogram, all the results relating to the MRC, MRCH, MRCc, MRcag, and MRcal series, which were obtained by substitution of lime transformed into aerial lime, indicate that handling has decreased in the last two series, i.e., MRcag and MRccal. Considering the value of the ratio $\mathrm{W} / \mathrm{C}=0.43$, the absorption is more significant which results in a reduced spread of mortar due to the presence of limestone, gypsum, and sand. We also noticed that when the report W/C ratio was generally maintained around 0.43 , this variation depended on the limestone content of the air lime and also on the sand additions where the quotient was a function of the effect generated by the air lime. Different mixtures are also confirmed by Azeredo et al. 2007.

On the other hand, Fauck (1973) suggests that the morphological convergence of red ferrallitic soils on sandstone and on basalt is based on common characters, in particular on reddening and the creation of pseudo-particles. This convergence is due to various important reasons including the presence of free alumina. This is certainly due to the presence of very small amounts of uncombined silica (quartz) in the materials. This free alumina, in the form of gibbsite, increases towards the top of the profiles. Its presence characterizes a more advanced stage of kaolinite degradation. Obviously, this stage could not be reached in the case of soils of sandstone materials, probably due to the fact that these soils are rich in uncombined silica, the role of which can only be justified by a sufficient release of silica in solution, which allows the alumina from recombining to reform kaolinite. It should be noted that when the quartz contents are insufficient, this recombination cannot occur.

\section{Formulation of mortars}

The tests were carried out on mortars having a standard composition upstream. Furthermore, the control mortar was obtained by a standard composition containing cement $(100 \%)$, sand, and water. A second preparation is based on lime (100\%), sand, and water. Based on the standard preparation, it was decided to develop other mortars by adding cement (50\% of lime, $50 \%$ of cement). The various mortars were made with a water-to-cement (W/C) ratio successively equal to $0.5,1.15$, and 1.4. The preparation of mortars took place under the same conditions, as required by standard NF EN 196-1. Likewise, the test protocol for the other series obtained under the same conditions was applied while replacing the mass fraction of cement with lime.

For the purpose of achieving the desired goal, three series of mortars were made by varying manually the dosage of aerial lime and cement; the (W/C) ratio was varied as well. The compositions of the mortar mixtures under study are summarized in Table 4.

\section{Mortar in the dry state}

\section{Preparation of test specimens}

The test samples were prepared in prismatic molds $(40 \times 40 \times 160) \mathrm{mm}^{3}$, according to Standard NF P 15-403. By also respecting the technique of introducing successive layers of mortar into a metal mold with three cells in order to avoid leaks play an intrinsic role in the production of material obeying the technical rules of execution, this test is carried out with an elevation, on an impact table. The different layers and then spread evenly, using the large spatula, then tightened by 60 shocks. The second layer is then introduced, leveled by means of the spatula, and tightened again by 60 shocks.

\section{Mass loss}

The mass loss measurements were made on test specimens stored in the open air. This mass loss was measured at different ages. All measurements were carried out at room temperature and at a temperature of $60{ }^{\circ} \mathrm{C}$ because the latter has an effect on the increase of the interaction effect of the substituted components in the cured mortars (Fig. 4).

As for the density, it was determined by considering the ratio between the mass of the $4 \times 4 \times 16 \mathrm{~cm}^{3}$ specimens and the apparent volume, after the 28 -day cure $\left(20^{\circ} \mathrm{C}\right.$, $R H=98 \%$ ). Note also that the specimens were dried in an 
Fig. 4 Cement mortar (a) and lime mortar (b)

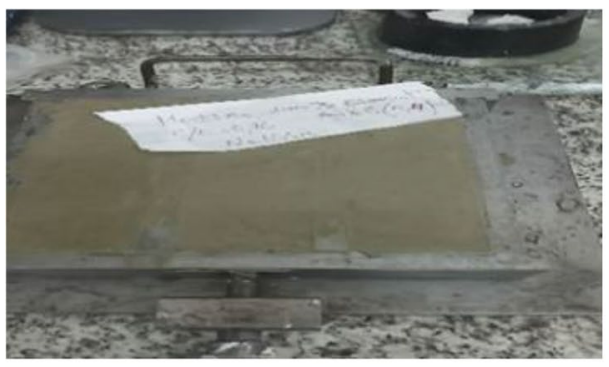

(a)

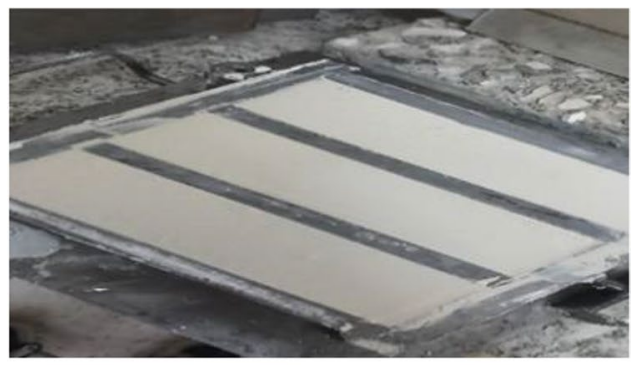

(b)

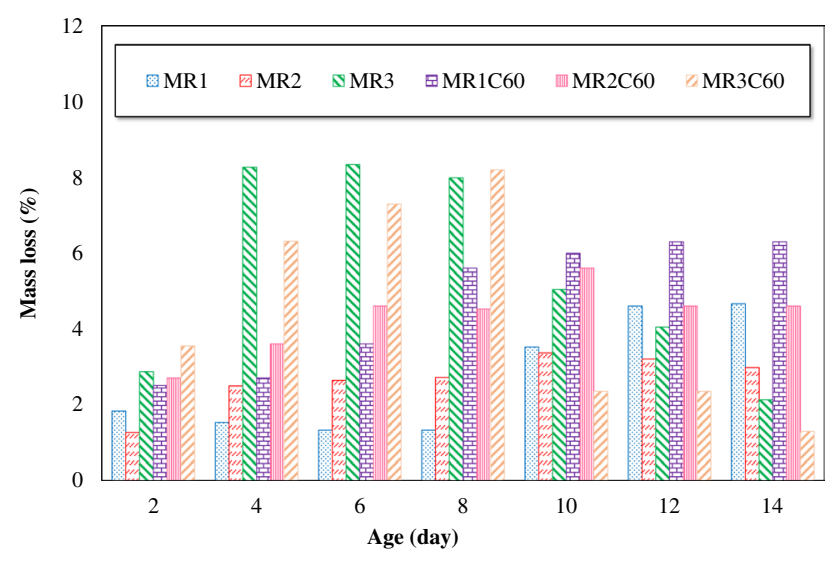

Fig. 5 Variation of mass loss over time

oven at $50{ }^{\circ} \mathrm{C}$ until a constant mass was reached. Figure 5 clearly shows the effect of changing the percentage of lime replacement of cement.

Figure 5 shows that mass loss increases rapidly at early ages, until eighth day. Then it starts decreasing until stabilization (Pieri 2019). Beck et al. (2007) found out that slaked lime increases the density and homogeneity of mortar; it also gives mortar the potential to compensate for shrinkage phenomena. It is a deformable element that sits between the grains of sand and cement in mortar.

\section{Destructive testing}

The mechanical strength of the mortars under study was determined through destructive bending and compression testing on specimens of dimensions $(4 \times 4 \times 16) \mathrm{cm}^{3}$ at different ages, i.e., 7, 14, and 28 days, in order to see the progressive evolution of performance knowing that all the destructive tests performed on the prepared specimens were carried out according to Standard EN 196-1. Furthermore, the density values were determined by considering the ratio between the mass of specimens and their apparent volume, after the 28 -day cure $\left(20^{\circ} \mathrm{C}, \mathrm{RH}=98 \%\right)$. The test pieces were dried in an oven at $60{ }^{\circ} \mathrm{C}$ until mass stabilization.

Figure 6 shows the failure mode in a hydraulic press that was used in our experimental campaign to measure the mechanical strengths of the mortars studied.

Figures 7, 8, and 9 illustrate the evolution of the physical and mechanical properties as a function of days. It is noted that the flexural strength reductions through traction are less important for mortars containing $100 \%$ lime, probably due to their plasticity. In addition, the compressive strengths fell by $35 \%$, while the flexural strengths fell by only $10 \%$. This may be explained by the fact that the compressive strengths for these specimens from the bending tests were very low and also the bending test the broken halves show micro-cracks inside them, caused by loading. This causes a decrease in addition to the load; the broken halves have undergone a certain force or vibration during sawing (surfacing) (Azeredo et al. 2007).

The variation of the compressive strength as a function of dry density is shown in Fig. 10. The proposed relationship is such that:

$$
R_{\mathrm{C}}=0.193 \mathrm{e}^{0.0032 \rho} \text {. }
$$

where $R_{\mathrm{c}}$ is the compressive strength and $\rho$ is the density; the correlation coefficient is equal to 0.9734 . It should

Fig. 6 Bending tensile test
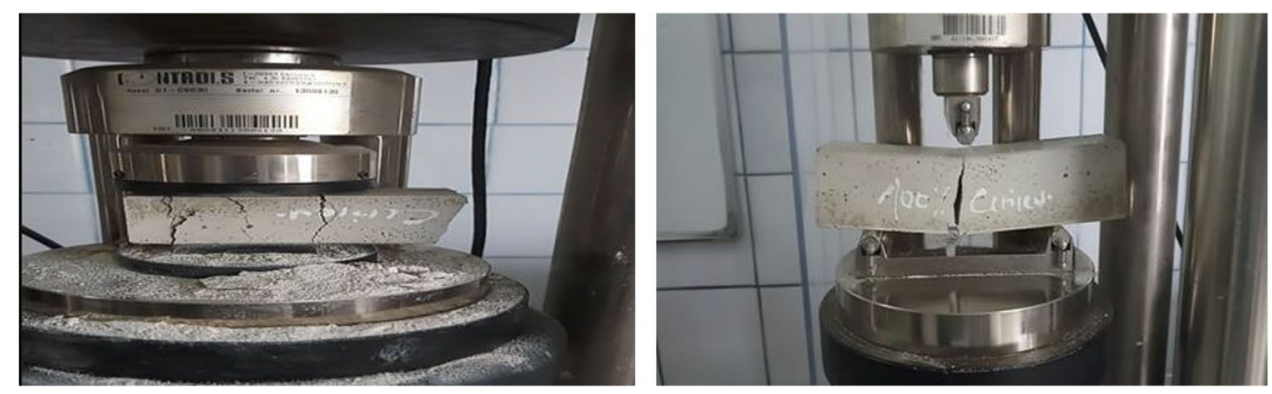


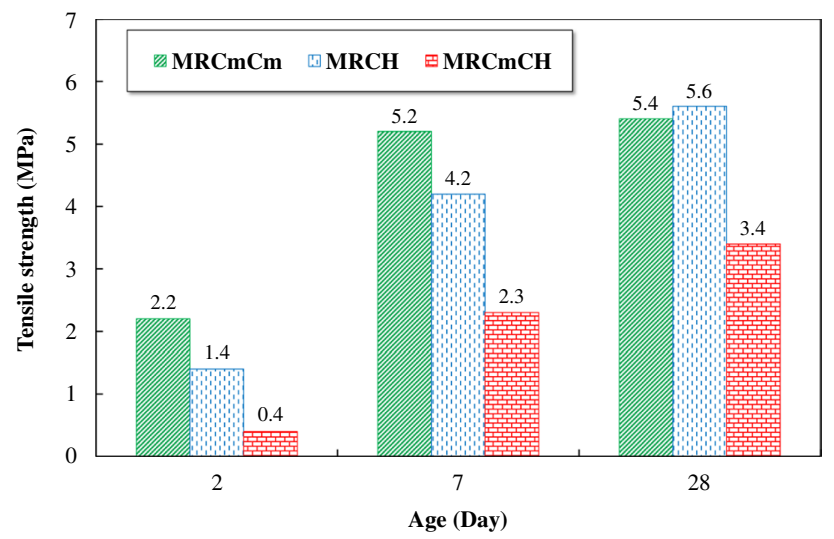

Fig. 7 Bending tensile strength of the different mortars

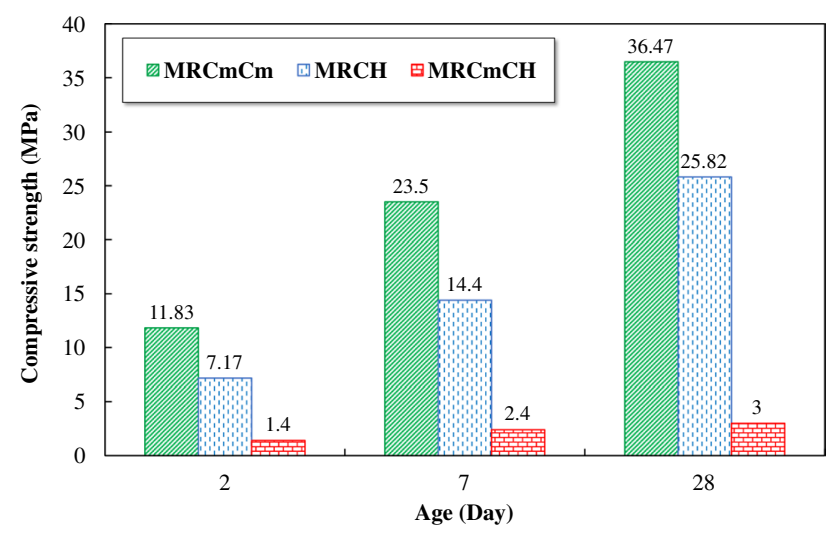

Fig. 8 Increase in compression of different series of mortars

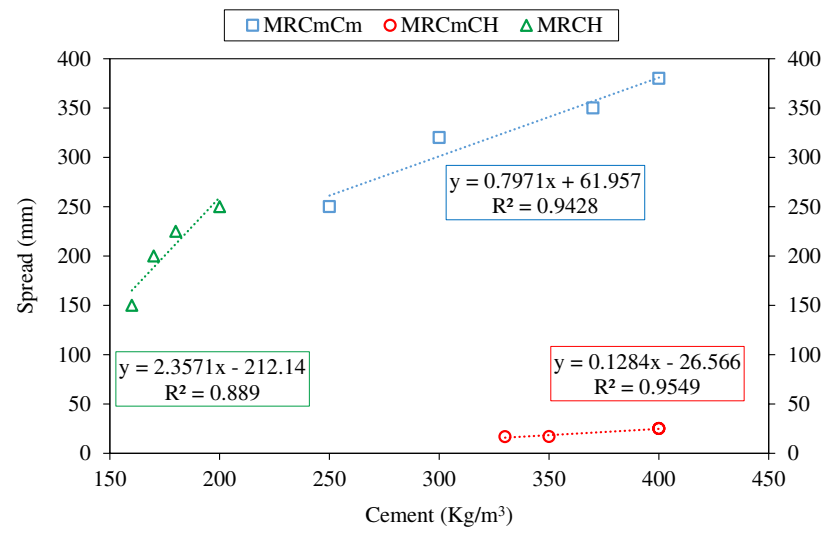

Fig. 9 Influence of cement on the physical properties of mortars

be specified that lime increases the density of mortar. This expression is similar to that reported by previous studies carried out on lime mortars (Menadi et al. 2013).

The slow setting of lime-based mortars, shown in Fig. 10, is much smaller than that of cement-based mortars. The

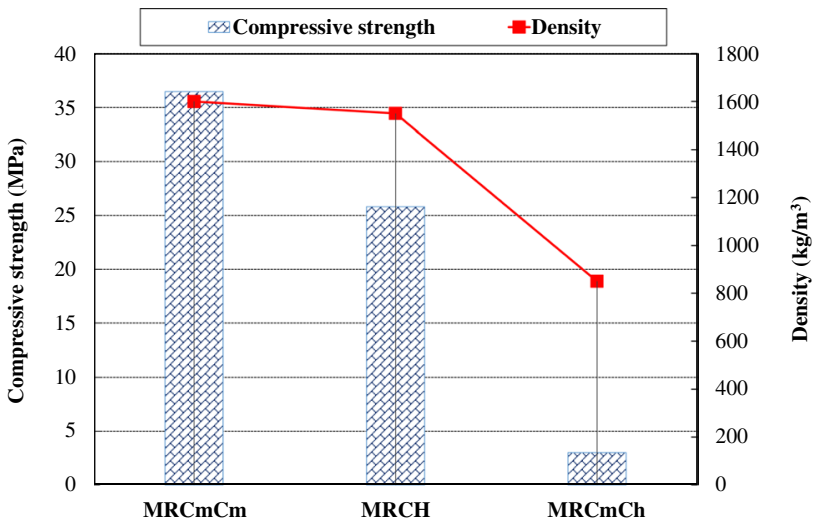

Fig. 10 Compressive strength at 28 days as a function of density

compressive strength of lime mortars can increase well beyond the standard 28-day cure time, which is normal because lime is a set retarder.

This finding about the compressive strength of lime-based mortars, which can increase significantly after the 28-day standard ripening time, was also confirmed by Beck et al. (2007).

\section{Grout setting and measurement of setting time}

The consistency test helps to determine the optimum amount of water needed for mixing a binder in order to obtain a normal consistency paste. This consistency would correspond to a specified resistance to the penetration of a standardized probe, with a water-to-cement (W/C) ratio equal to 0.21 , in accordance with Standard NA442 CEM II/B-L 42.5 N.

Kaolinite is a clay that gives mortar a certain plasticity (Krasniqi 2019). It is worth recalling that kaolinite was also used in ancient times to delay the drying of mortar blocks, thus allowing workers to do a better job. The surface area of kaolinite particles is equal to 2 . In the same shutter, the kaolinite has an adsorption which allows workers to carry out construction work under ambient temperatures which can sometimes exceed $40{ }^{\circ} \mathrm{C}$, while avoiding the phenomena of endogenous shrinkage and desiccation of mortar blocks and joints. The incorporation of kaolinite promotes the entrainment of air into mortar and increases its porosity. Also, with the addition of fine sand, the prepared material loses its hardness. These findings have equally been reported by other researchers (Beck et al. 2007; El Korhani et al. 2019). It is important to note that porosity and density are two parameters that are inversely proportional to mechanical performance.

On the other hand, it should be known that the quicklime blocks are extinguished by sprinkling the coarsely crushed blocks. The lime thus obtained is only partially slaked and 
still has quicklime nodules that can cause craters in the plaster while hydrating (Pieri 2019).

This part is devoted to the preparation of grout using fatty lime and incorporating kaolinite, as shown in Table 4. It is widely acknowledged that this clay helps to stabilize lime. Moreover, its adsorption was found to be a fairly important liquidity factor during the grout injection of grout which serves to remedy stylolithic joint-type cracks. A simple analysis allowed identifying the different constituents and their nature. It therefore became more interesting to attempt to quantitatively reconstitute the composition of the material using the setting time and consistency tests.

\section{Composition of the different grouts}

The mortars used in the second phase were named as follows:

- Mortar 1: 50\% lime, 50\% sand; CCHSa

- Mortar 2: 50\% cement, 50\% fine grain sand; $\mathrm{CCmSa}$

- Mortar 3: $100 \%$ cement; $\mathrm{CCmCm}$

- Mortar 4: 65\% slaked lime, 35\% kaolinite, fine grain sand; CCHKSa

It is easy to notice that when the substitution rate increases, the compressive strength of mortar decreases. Consequently, the amount of water needed for the preparation of the mortar paste will be taken as equal to the quantity of water corresponding to the liquidity limit. Indeed, this is done in accordance with the compatibility criteria between lime-based mortars and the high porosity limestone such as white tuffeau (Pieri 2019).

Figure 11 illustrates the arrangement of the stone blocks. The incorporation of lime, such as aerial lime which promotes gas exchange inside the walls, helps reduce the humidity level in these walls. Among others, the fineness of lime is very important because it offers exceptional smoothness and adhesion to supports. Moreover, the slaked aerial lime shows a homogeneous and constant pure white color, with a finesse that allows highlighting the color of the local sands.

As a result, some researchers indicated that mortars can be prepared with lime slurry in advance, without any time limit for their application (Traunecker 1972; Martinet 1992). It should be mentioned that the sandstone used in constructions was brought from Gebel Silsila quarries near Aswan, about $100 \mathrm{~km}$ south of Luxor. It is siliceous sandstone, cemented by iron oxides in small proportions (1-2\%) which gives it a yellow to brown color. It is not very resistant, especially in humid environments. Its porosity is quite high, between 18 and $25 \%$, or even $28 \%$, according to certain sources (Traunecker 1972; Martinet 1992).

The consistency results shown in Fig. 12 indicate that some grouts, such as $\mathrm{CCmSa}$ and $\mathrm{CmCm}$, are found below the standard depth of $5 \mathrm{~mm}$. This is probably due to the rapid hydration of cement and sand of granular fraction (0/1), which caused the desiccation of grout and rapid setting of mortars.

The grout setting results shown in Fig. 12 and Fig. 13 clearly show that excess water is often detrimental to the mechanical behavior of cementitious materials. The incorporation of kaolinite (clay) provides some plasticity and resistance to grout and also some strength to mortars. In ancient times, kaolinite made it possible to delay the drying of stone blocks and in particular to facilitate the work of builders on construction sites. Kaolinite provides the appropriate hydraulicity which facilitates processing; it also delays the hardening of materials for which this property is necessary in order to achieve a good quality work.

According to some researchers, mullite and cristobalite crystallization can be considered, but this occurs preferentially at temperatures above $1050{ }^{\circ} \mathrm{C}$ (Mohammadi and Pak 2003; Doğan et al. 2008; Ilic et al. 2010; Ptáček et al. 2010).
Fig. 11 Color conservation of joints and stone blocks

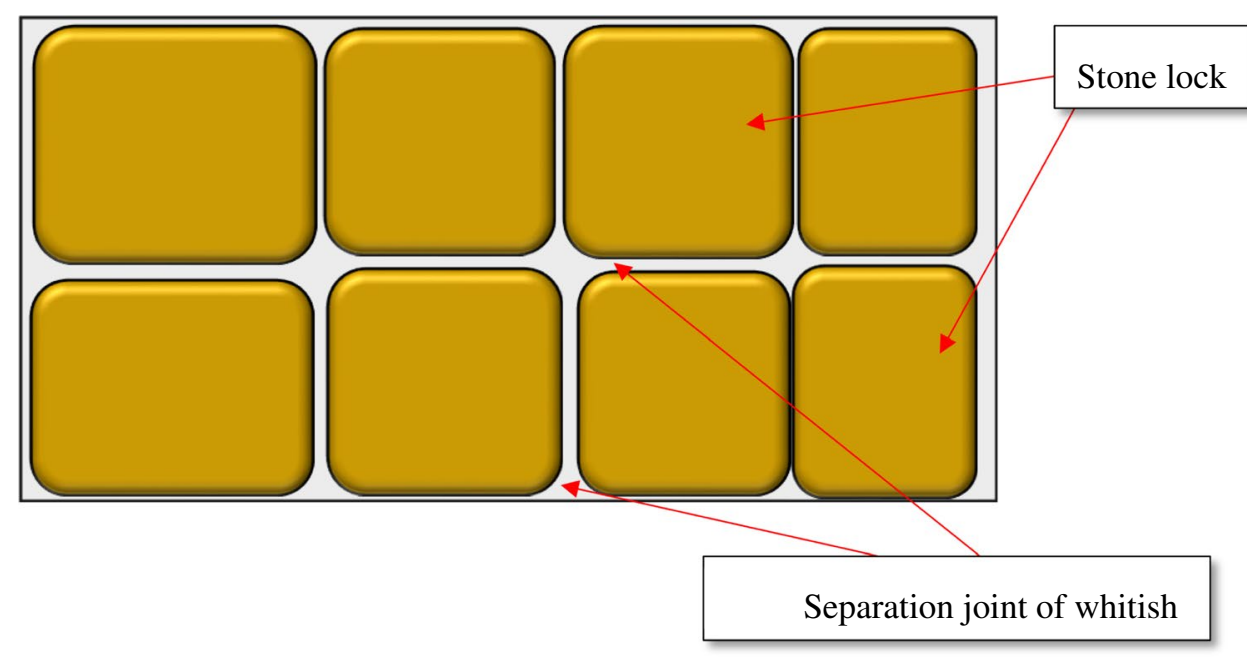




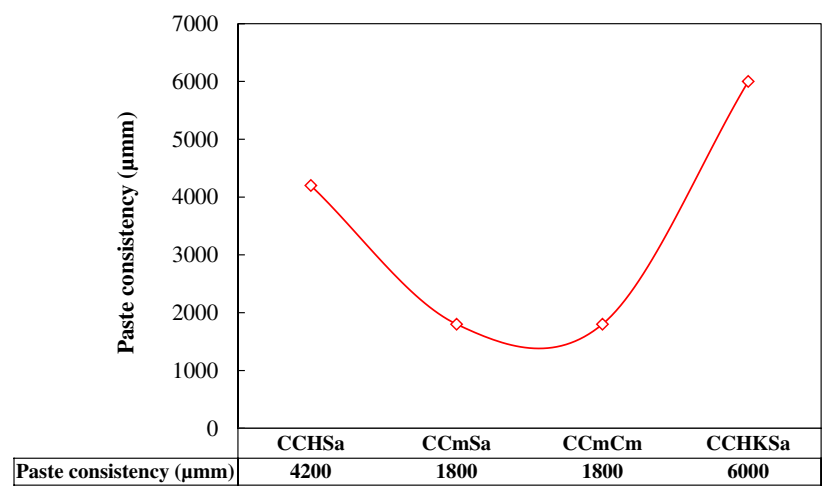

Fig. 12 Consistency of different series of pastes

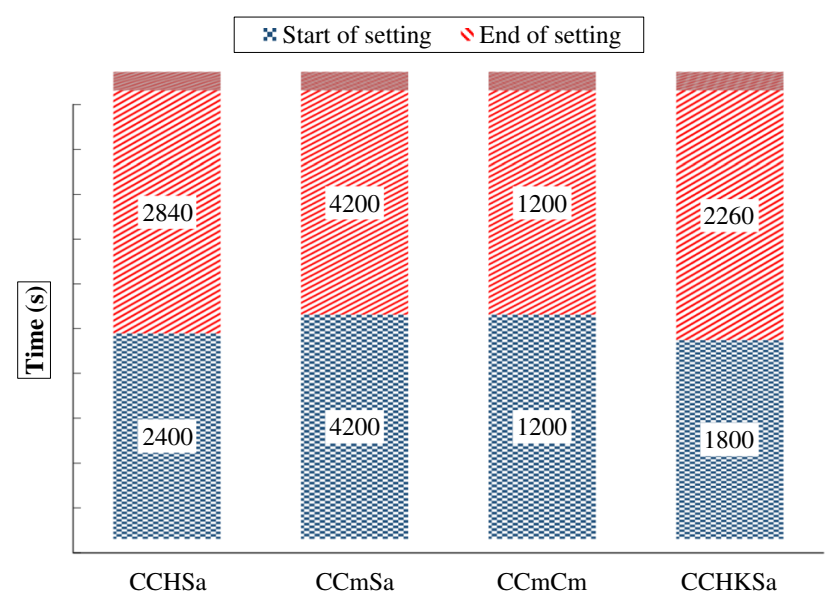

Fig. 13 Grout setting

From Fig. 14, Fig. 13, and Fig. 12, one may clearly see the effect of setting time which shows the predictable water excess that is often detrimental to the mechanical behavior of cementitious materials. It is worth reminding that kaolinite delays the setting of grouts observed in the CCHKSA series. This type of mineral clay (kaolinite) gives the grout adequate plasticity and strength to remedy cracks.

It should also be noted that the CCHKSA series is characterized by a slower setting which is necessary for better adaptation and good adhesion under the high temperatures to which the Egyptian pyramids are exposed. This slow setting greatly helped to delay the drying effect of stone blocks in ancient times and also enabled workers to do smarter work.

For stylolithic joints with an apparent opening of the order of $1 \mathrm{~mm}$ thick, the penetration depth of grout due to gravity did not exceed $5 \mathrm{~cm}$ during the tests and can reach 10 to $12 \mathrm{~cm}$ by injection under pressure. Despite the highwater dosage, any opening in the stylolithic joint is always adhesive and occurs by disintegration of the grout from its thickness (ICOMOS FRANCE 1999).

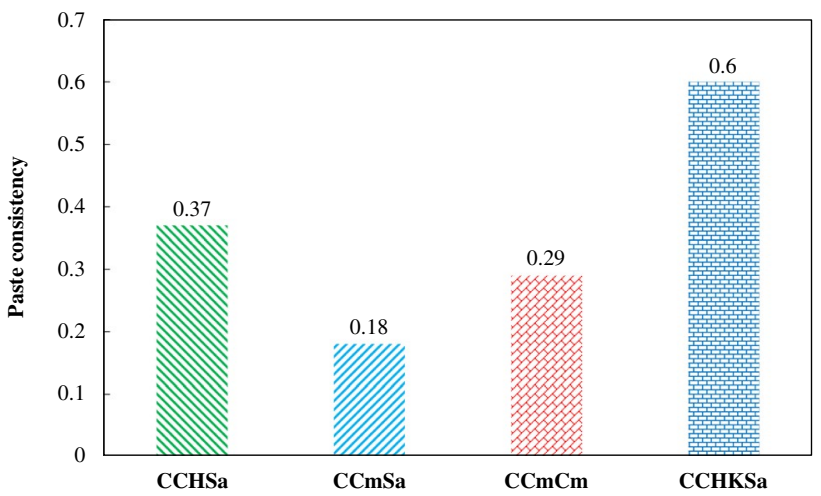

Fig. 14 Variation of consistency for different mortar mixes

Over the last few years, inorganic materials, such as ceramics, have increasingly attracted a great number of chemistry researchers because of their great chemical, thermal, and mechanical stability and their rather interesting porosity. The TGA data obtained by these researchers can be used for the formation of membrane supports because the gas released during the decomposition of calcite can improve the porosity of the support (El Korhani et al. 2019).

On the other hand, these same researchers, i.e., El Korhani et al. (2019) as well as Beck et al. (2007), suggested that the addition of kaolinite promotes the entrainment of air into mortar and increases its porosity. Adding that, the incorporation of fine sand reduces the setting rate of the material.

\section{Conclusion}

This study focused on the building materials of the pyramids of Egypt. It is made possible through experimental tests, to highlight the valorization of an old material, in this case lime, which can be used as a partial replacement of Portland cement for the preparation of mortar. The present work made it possible to collect a lot of results.

A great deal of interesting information on old traditional mortars was collected in this study and was then compared with new mortars. This study helped to better understand the ancient processes of construction and preparation of materials used in the antiquity.

- It was possible, through this work, to understand the extent of the works of past times, the ingenuity of ancient builders and Egyptian chemists who succeeded in adding kaolinite clays to obtain a better lime hydraulicity, thus giving the builders the possibility of doing a better work on these majestic monuments which are part of the wonders of the world in the Nile region. It should also be remembered that the archeological mon- 
uments in Algeria were made with techniques similar to those used in the construction of pyramids in Egypt.

- A protocol was used upstream to determine the physical and mechanical properties of mortars, as well as the sizes and shapes of aggregates, and the nature of the binder used. The manufacturing method with the appropriate proportions, the preparatory methods of mixing, the means of implementation, and storage conditions (temperature, humidity) have all been determined. For this, a guideline of our research was elaborated in the laboratory in order to better understand the preparation methods of construction materials used by the ancient Egyptians. Thus, lime mortar may be viewed as a link between the past and the present.

- In order to better elucidate the construction method adopted in Egypt and Algeria, it must be considered that the materials used, i.e., cement and lime, were selected on the basis of several factors, in particular the geographical location of the two countries and the similarities between the materials found in these two places, as they both belong to the north of the African continent.

- The different mortar formulations were used to establish a link between the past and the present using natural sand in order to imagine and position the pyramids with respect to the south and north of Algeria, by replacing these series of mortars by materials such as lime and kaolinite which have extensively been used in ancient and modern history for the construction of buildings.

- Kaolinite is a type of clay whose adsorption property represents a big advantage for builders working in ambient temperature conditions above $40{ }^{\circ} \mathrm{C}$. This makes it possible to avoid the emergence of laitance and the phenomena of endogenous shrinkage and desiccation of stone blocks and joints and possibly segregation.

- Given the current situation of the COVID-19 pandemic, some tests could not be completed.

Acknowledgements We would like to thank the staff of the ETP Hasnaoui Laboratory for their precious collaboration.

\section{Declarations}

Conflict of interest The authors declare that they have no competing interests.

\section{References}

Arnaud C (2003) Pétroarcheologie du mortier de chaux gallo-romain. Essai de reconstitution et d'interprétation des chaînes opératoires: du matériau au métier antique. Université Panthéon-Sorbonne Paris I
Arnaud C (2009) Les mortiers de chaux, Errance

Anas N, Chaabane LA (2019) Choix des matériaux locaux du sud Algérien pour le traitement et la stabilisation des sols en place. 22:303-314

Azeredo G, Morel J-C, Barbosa NP (2007) Compressive strength testing of earth mortars. J Urban Environ Eng 1:26-35

Beck K, Bigas JMJ, Al-mukhtar XBM (2007) Critères de compatibilité entre des mortiers à base de chaux et des pierres calcaires à forte porosité ( tuffeaux blancs ). Proc 25e rencontres l'AUGC 2-10

Bouanane Khentouche N (2008) Le Patrimoine Et Sa Place Dans Les Politiques Urbaines Algeriennes. UNIVERSITE MENTOURI

Charola AE, Dupas M, Sheryll, Richard P, Freund GG (1984) Characterization of ancient mortars: chemical and instrumental methods. In: Montedison progetto cultura (ed) Symposium on scientific methodologies applied to works of art. Milan, pp 28-33

Doğan M, Yilmaz Z, Alkan M (2008) Characterization and rheological properties of kaolinite-silicon oil pastes. Ind Eng Chem Res 47:8218-8227. https://doi.org/10.1021/ie800727d

El Korhani O, Souaidan M, Zaouk D et al (2019) Characterization of natural Lebanese clays for the preparation of ceramic membranes designed to water filtration. Leban Sci J 20:451-467. https://doi. org/10.22453/LSJ-020.3.451-467

Fauck R (1973) Les sols rouges sur sables et sur grès d'Afrique occidentale. Earth-Science Rev 9:296. https://doi.org/10.1016/00128252(73)90128-1

ICOMOS FRANCE (1999) La consolidation des mortiers dans les maçonneries anciennes : les coulis d' injection dossier technique La consolidation des mortiers dans les maçonneries anciennes les coulis d' injection. In: ICOMOS FRANCE (ed) The international technical day. Paris

Ilic B, Mitrovic A, Milicic L (2010) Thermal treatment of kaolin clay to obtain metakaolin. Hem Ind 64:351-356. https://doi.org/10. 2298/HEMIND100322014I

Krasniqi F (2019) Grande Pyramide K 2019

Kribeche J YA (2012) Manuel des typologies constructives, architecturales et architectoniques de la vieille ville de Constantine

Lynda Amel C, Kadri E-H, Sebaibi Y, Soualhi H (2017) Dune sand and pumice impact on mechanical and thermal lightweight concrete properties. Constr Build Mater 133:https://doi.org/10.1016/j. conbuildmat.2016.12.043

Maamar L (2009) Etude de réhabilitation d'un immeuble vieux bâti à Oran. In: SBEIDCO. Oran, Algeria, pp 335-342

Mannoni T, Pesce G, Vecchiattini R (2006) Mortiers de chaux dolomitique avec adjonction de kaolin cuit : 1 ' expérience génoise

Martinet G, Quenee B Proposal for a useful methodology for the study of ancient mortars. 81-91

Martinet G (1992) Grès et mortiers du temple d'Amon à Karnak, HauteEgypte : étude des altérations, aide à la restauration, Laboratoir

Menadi S, Douzane O, Merzoud M, Habita F (2013) Etude De La Faisabilite D'un Composite 49:40-49

Mertens G, Elsen J, Laduron D, et al (2006) Minéralogie des silicates de calcium présents dans des mortiers anciens à Tournai. 1-6

Michel F (1975) Mortiers et enduits peints antiques: étude technique et archéologique, Centre de

Mohammadi T, Pak A (2003) Effect of calcination temperature of kaolin as a support for zeolite membranes. Sep Purif Technol 30:241-249. https://doi.org/10.1016/S1383-5866(02)00146-6

Muzahim Al-Mukhtar KB (2005) Caractéristiques d'un mortier é a base de chaux et de poudre de roche pour la restauration des monuments. In: Rencontre Internationale sur le Patrimoine ArchitecturalMéditerranéen, eknès, Maroc. $\mathrm{p} 6 \mathrm{P}$

Pacheco-Torgal F, Faria J, Jalali S (2012) Some considerations about the use of lime-cement mortars for building conservation purposes in Portugal: a reprehensible option or a lesser evil? Constr Build Mater 30:488-494. https://doi.org/10.1016/j.conbuildmat. 2011.12.003 
Palazzo-Bertholon B (1999) Archéologie et archéométrie des mortiers et des enduits médiévaux. Etude critique de la bibliographie. Archéologie Médiévale 29:191-216. https://doi.org/10.3406/ arcme.1999.938

Peter E (2001) Gauging lime mortars. In: Build. Conserv. Dir. https:// www.buildingconservation.com/articles/limegauging/limegauging.htm

Pieri L (2019) Égypte : vers une restauration durable et locale, production et diffusion de l'emploi de la chaux pour le ragréage du grès au temple de Ptah à Karnak. 4-13

Ptáček P, Kubátová D, Havlica J et al (2010) The non-isothermal kinetic analysis of the thermal decomposition of kaolinite by thermogravimetric analysis. Powder Technol 204:222-227. https:// doi.org/10.1016/j.powtec.2010.08.004

Qualiroutes (2011) CAHIER DES CHARGES TYPE CHAPITRE C MATERIAUX ET PRODUITS DE CONSTRUCTION

STAP du Calvados (2013) Intervenir sur le bâti ancien

Sumera F, Veyrat E (1997) Les fours à chaux gallo-romains de "Brétinoust", commune de Sivry- Courtry (Seine-et-Marne). Rev Archeol Centre France 33:99-130
Traunecker C (1972) Aperçu sur les dégradations des grès dans les temples de Karnak. In: Extrait des Cahiers de Karnak 5, 1975. pp 119-130

Vaschalde C, Thiriot J, Rammah M, Chéhaibi Z (2010) Fours à chaux et chaufourniers et Méditerranée occidentale : ethnoarchéologie de l'art de cuire la pierre. In: Métiers, savoir-faire et vie professionnelle dans le monde méditerranéen d'après les sources archéologiques. Actes du IIe colloque international de l'Institut Supérieur des Métiers du Patrimoine de Tunisie. Jarray F. éd., Tunis, Institut Supérieur des Métiers du Patrimoine, pp 185-198

Vaschalde C, Bromblet P, Büttner S (2016) Gamme de chaux dans les économies anciennes. Méthodes de prélèvement et d'identification des types de chaux dans les fours (DRX, MEB-EDS, pétrographie) (Antiquité, Moyen Âge, époque moderne). ArchéoSciences 119-135. https://doi.org/10.4000/archeosciences.4801

Weber \& Broutin (2007) Restaurer le caractère du bâti ancien 